\title{
Fresh Water Algae from Vena River Hinganghat Dist. Wardha Maharashtra, India
}

\author{
*Rajurkar B. M. And L. P. Dalal** \\ *Department of Botany, R. S. Bidkar College, Hinganghat Dist. Wardha (M.S.) \\ **Department of Botany, Jankidevi Bajaj College of Science, Wardha (M.S.)
}

\begin{abstract}
The present work is a part of survey conducted to study the fresh water algal flora of Vena River of Hinganghat tahsil of Dist. Wardha (M.S,), Twenty one taxa of class Chlorophyceae, Cyanophyceae and Bacillariophyceae were identified from 6 samples. Cosmarium reniforme (Ralf) Arch. and Roth. And Scenedesmus bijugatus (Turp.) Kuetz. were the dominant green algae followed by the remaining other rare species of Scenedesmus Meyen and Staurastrum Meyen ex Ralfs. All these taxa constitute new records for the study area.
\end{abstract}

Key words:Bacillariophyceae, Chlorophyceae, Cosmarium, Cyanophyceae, Fresh water algae, Scenedesmus, Staurastrum.

\section{Introduction:}

Hinganghat is one of the tehsils of Wardha District situated in $20^{0} 18^{1}$ to $20^{0}$ and $49^{1} \mathrm{~N}$ and $78^{0} 32^{1}$ to $79^{0} 14 \mathrm{E}$ latitude. The town is located on the bank of Vena river, a tributary of the Wardha river which joins the big river Pranhita, which ultimately merges into the Godavari river. In British India Hinganghat was the centre of India, but after the partition of Hindusthan into India and Pakistan, the Nagpur is considered as the center (heart place) of India. At vena river pump house there is an historical old stone, on which it was written that Hinganghat is the centre of India. The major portion of the total annual rainfall is received during June to September of each year. The average rainfall of Hinganghat Tahsil is $1071.70 \mathrm{~mm}$ and has a dry tropical weather climate. The climate is hot and dry. Max temp in ${ }^{0} \mathrm{C}$ were noted as $47.9^{0} \mathrm{C}$ and Min temp in ${ }^{0} \mathrm{C}$ were noted as $10.2^{\circ} \mathrm{C}$. The seasons of a year were divided climates into three season namely cold, hot and monsoon.

Wardha District has a typical seasonal mansoon, where people are engaged in agriculture. Hinganghat city lies in the south east of Wardha District. Its South East border touches Chandrapur District and South west border touches to Yeotmal District. The land scape of the city faces towards the south. There are fast running streams and Vena River bordering the north, west and south sides of the city. The city is rich in fauna and flora and water sources.

The contribution to the Vidarbha and Marathwada Chlorophycean, Cyanophycean and Bacillariophycean flora have been made by Tarar, J. L., and Seema Bodkhe (1998). Sarode , P. T., and Kamat, N. D. $(1979,1983)$. However, the morpho-taxonomic studies of Vidarbha fresh water algal flora have received very little attention (Das, 1961; Santra and Adhya, 1973, 1976; Alfred, 1978). That's why the present study was undertaken to explore the algal flora of Vena river. 


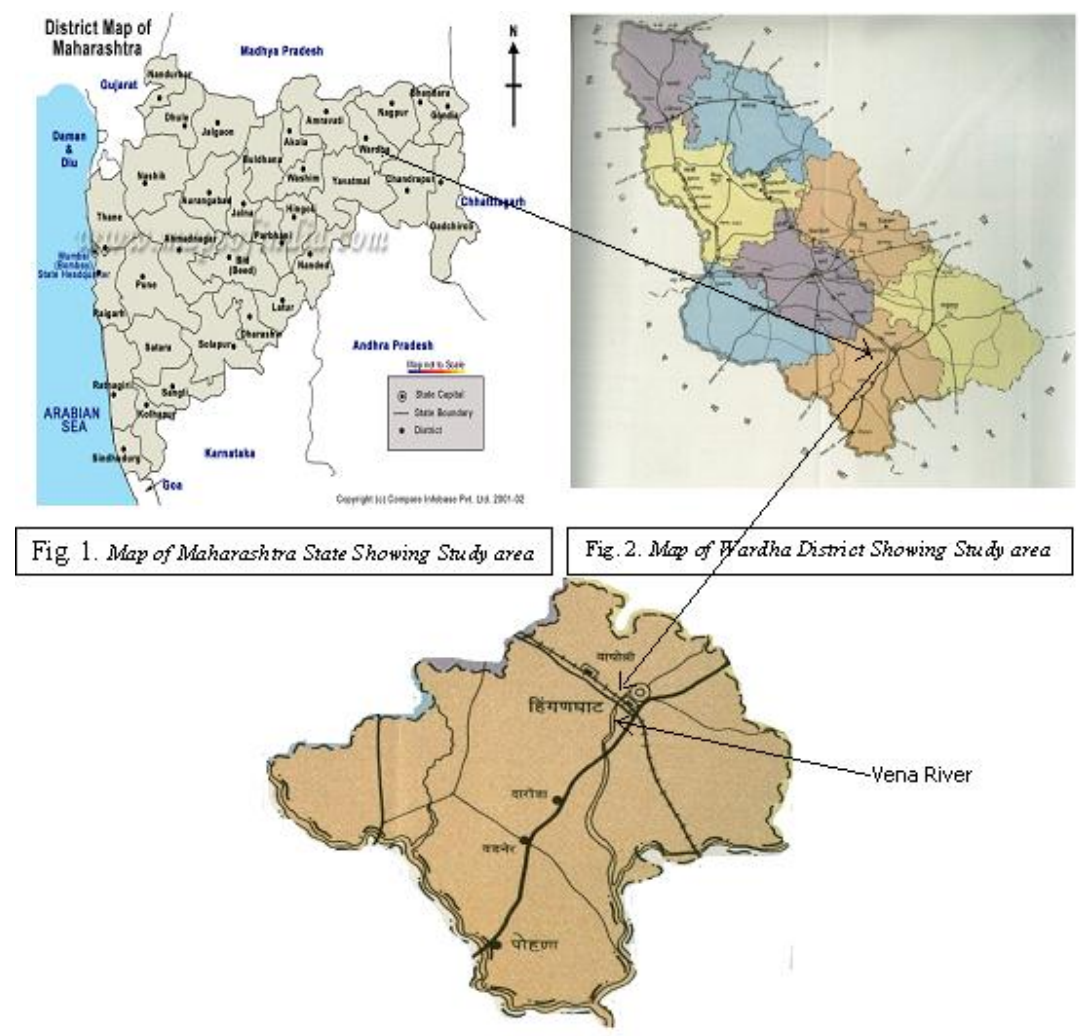

Fiz. 3. Map of Hinganghat tahil Showing Study area

\section{Materials and Methods}

For the experimental study samples were collected in the month of January 2012 in plastic tubes from different stations like Bridge, Kawalghat, Smashanbhoomi, Dunkin, Shalangadi and Ajanti dam with the help of plankton mesh net (size $0.5 \mathrm{~mm}$ ) and by scrubbing the slippery pebbles between 9-12 AM. All the samples were preserved in $4 \%$ formaldehyde solution on the spot. Geographical position, sample no., date of collection etc. of each locality was also enlisted in the field diary and were brought to the research laboratory of Department of Botany, J. B. College of Science, Wardha (M.S.) for further investigation. Diatoms frustules were cleaned following the Patrick and Reimer (1966) method. Microscope Image Projection System (MIPS) photograph have been taken and identified to species level by employing the monographs and research publications available with the college library. Identification was confirmed by cross checking of each specimen with literature and monographs (Desikachary, 1959; Scott and Prescott, 1961; Foged, 1971; Bharati and Hedge, 1982). All the samples have been deposited in the repository of Department of Botany, J. B. College of Science, Wardha (M.S.). Tarar J. L. (1998) had reported many interesting forms of algae from Vena River. The works in this district was unknown to the researchers, taxonomists etc.. In the present experimental work, a total 21 fresh water algae have been identified from streams and rivers of Vena River in Hinganghat area of Hinganghat tahsil of Wardha District (M.S.). The present study may help in the algal database of Vidarbha and to conserve aquatic biodiversity of this area.

\section{Observation and Result}

Extensive samples were undertaken personally from various stations of Vena river of Hinganghat area in order to understand the algal diversity in the area. The information was collected from available literature from books, internet and various scientific journals. Repeated queries were made to get the information confirmed. Merismopedia elegans A. Braun (fig. 4), Diatoma vulgaris Bory(fig. 5). Frustulia vulgaris var. asiatica Skvortzow (fig. 6), Scenedesmus bijugatus (Turp.) Kuetz (fig. 7), Pediastrum simplex Meyen (fig. 8), Cosmarium caelatum Ralf (fig. 9), Spirulina platensis (Gomont) Geitler (fig. 10), Navicula striatula (Turpin) Ehrenberg (fig. 11), Cosmarium leave var. validius Nordst. (fig. 12), Gomphonema christenserii R.L. Lowe et Kociolek (fig. 13), Cymbella tumida (Brabisson)Van Heurck (fig. 14), Cosmarium reniforme (Ralf) Arch (fig. 15), Mougeotia scalaris Hassall (fig. 16), Oscillatoria princeps var. minor Vaucher (fig. 17), Cosmarium microsphinctum var. crispulum Nordstedt (fig. 18), Amphora copulate (Kutzing) Schoeman \&Archibald (fig. 19), Coelastrum polychordum (Korschikoff) Hindak var. polychordum (fig. 20), Cosmarium depressum (Nageli) 
P.Lundell (fig. 21), Cymbellaaffinis Kutzing (fig. 22), Cymbella aspera (Ehrenberg) Cleve (fig. 23), Cymbella microcephala (Grunow) Krammer (fig. 24) these algal forms of the area are experimentally studied.

The microscopic photographs of the algal forms are given below.
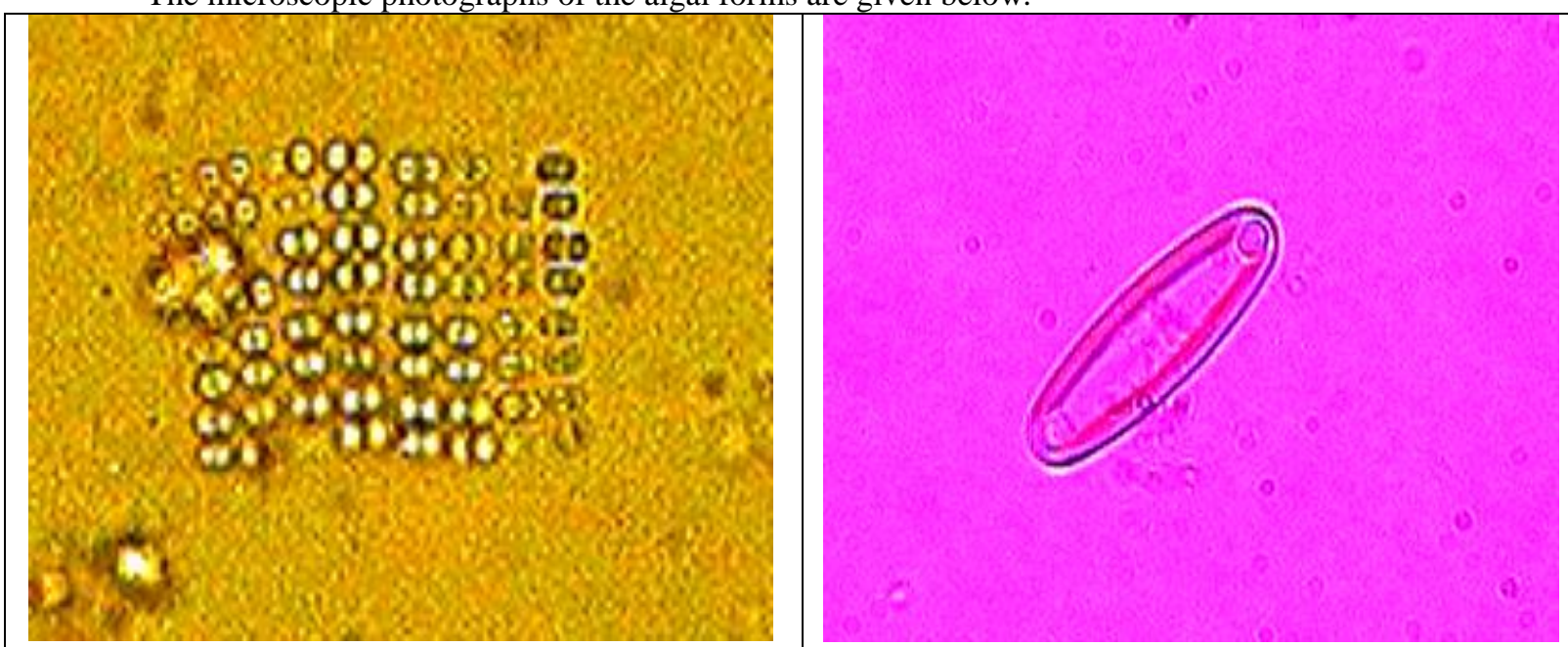

Fig. 4. Merismopedia elegans A. Braun

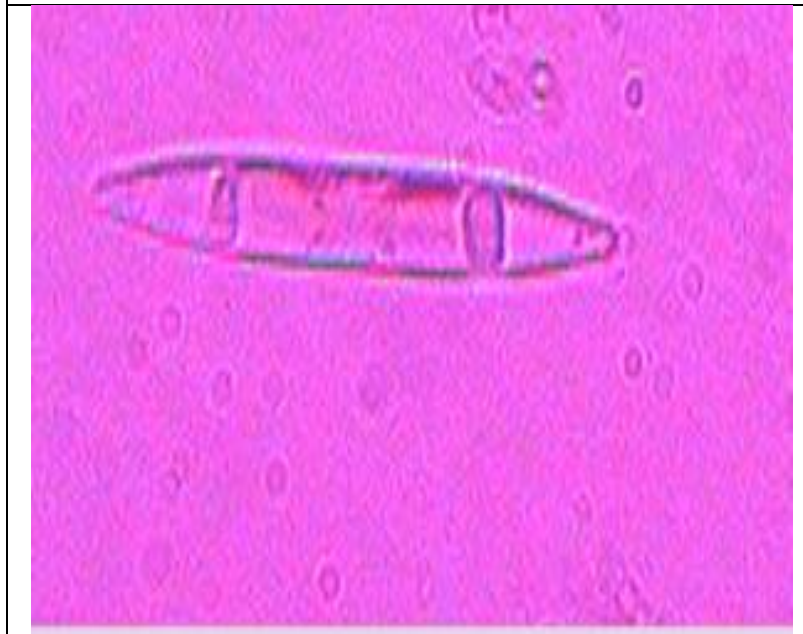

Fig.6. Frustulia vulgaris var. asiaticaSkvortzow
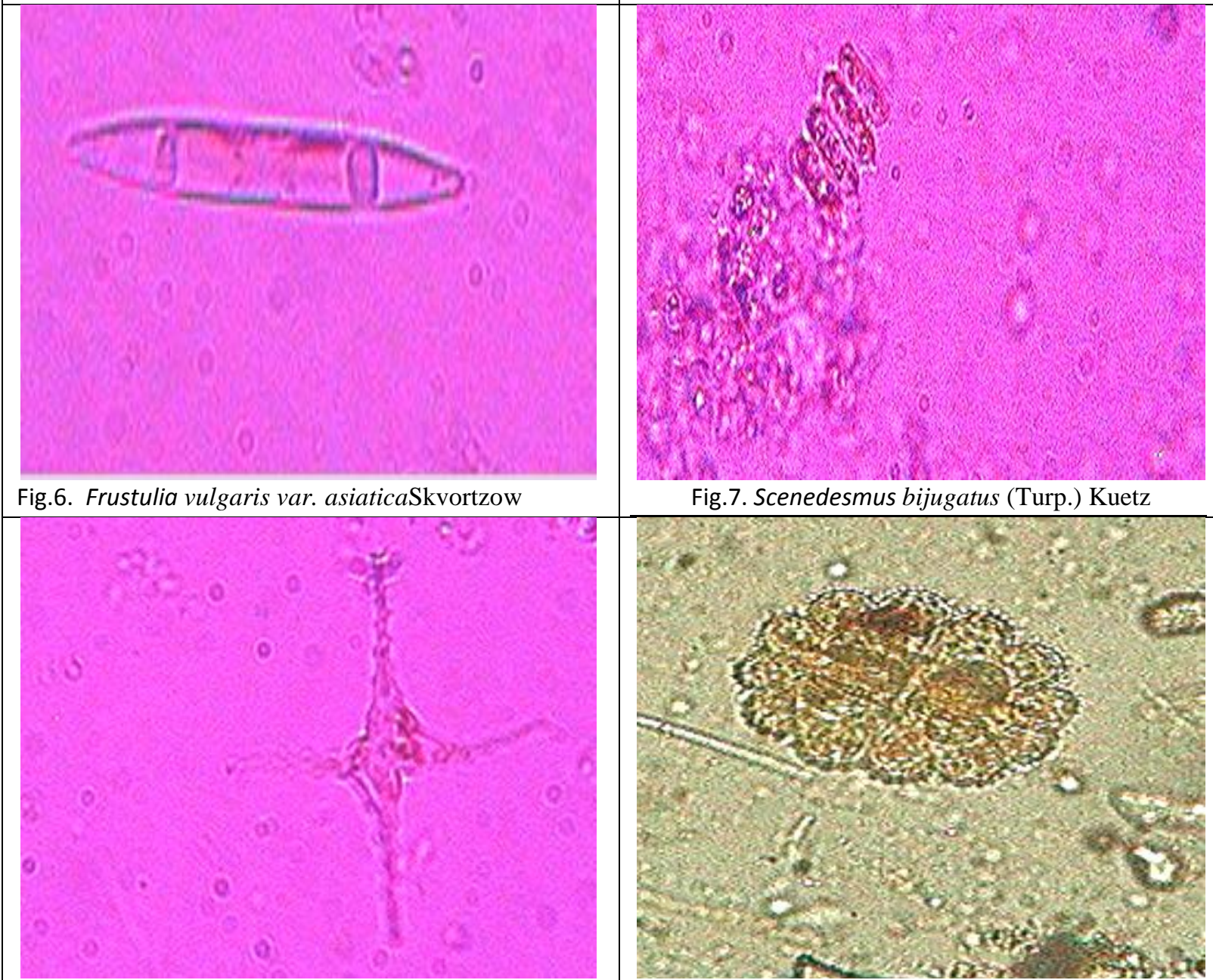

Fig.8. Pediastrum simplex Meyen

Fig.7. Scenedesmus bijugatus (Turp.) Kuetz

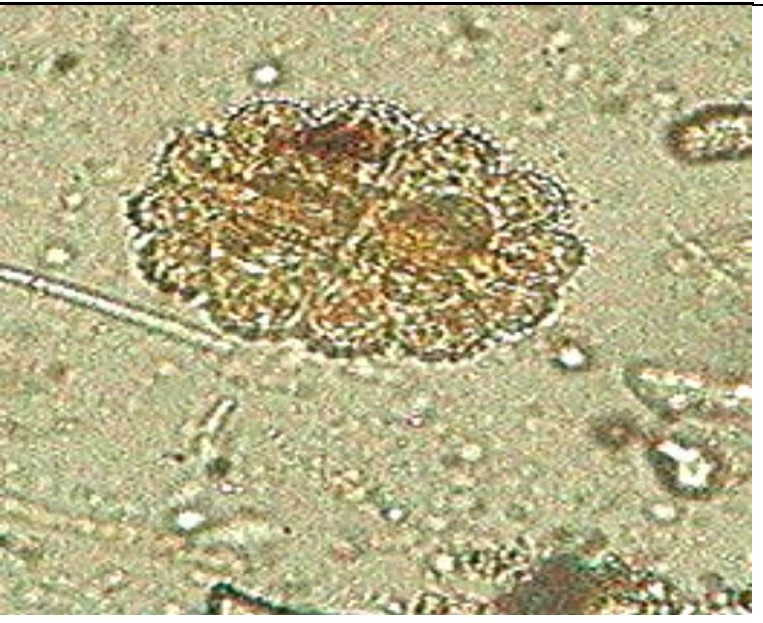

Fig. 9.Cosmarium caelatum Ralf 


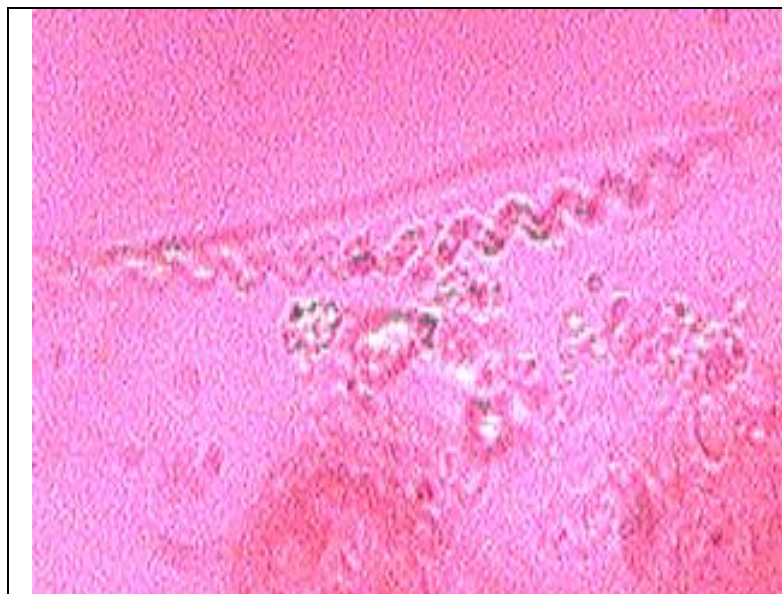

Fig.10Spirulina platensis (Gomont) Geitler

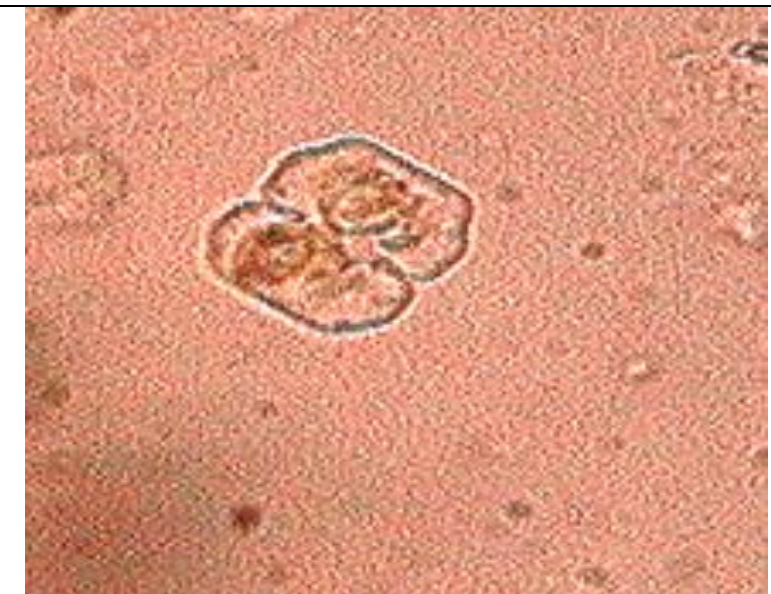

Fig.12Cosmarium leave Nordst. var. validius Nordst.

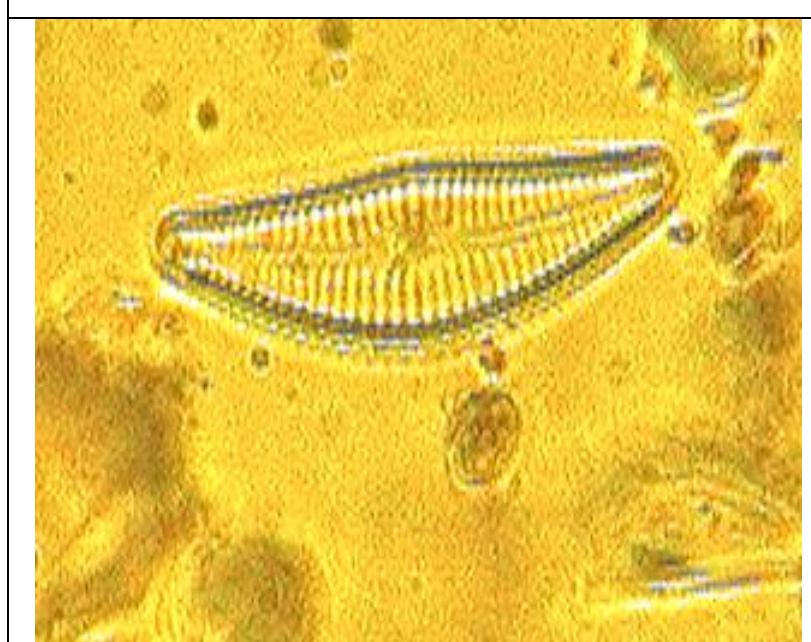

Fig. 14. Cymbella tumida (Brabisson)Van Heurck

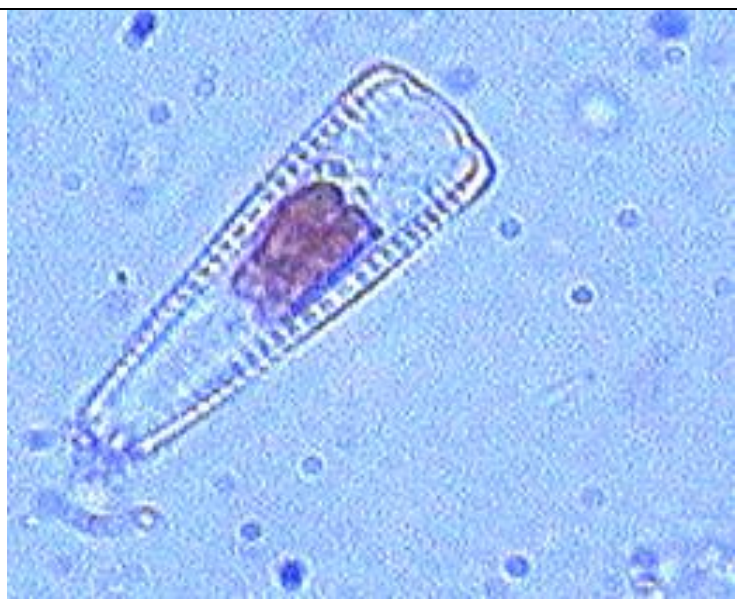

Fig. 11. Navicula striatula (Turpin) Ehrenberg

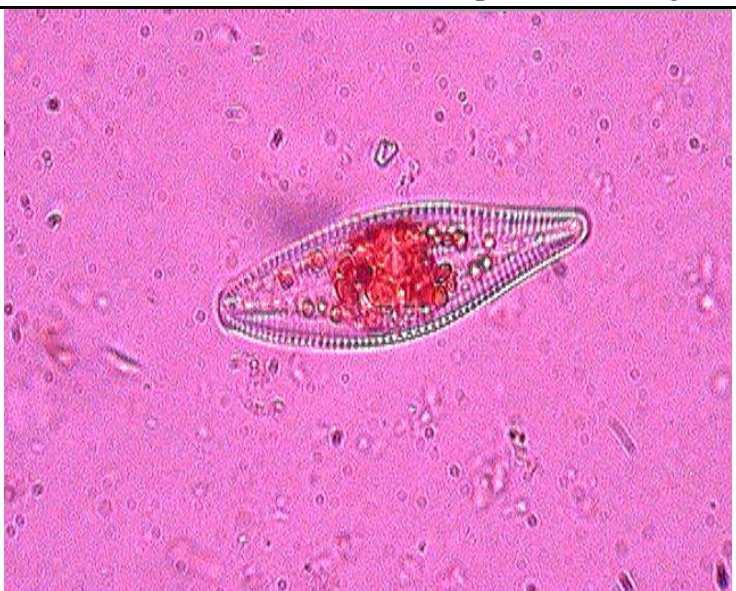

Fig. 13. Gamphonema christenserii R.L. Lowe et Kociolek.

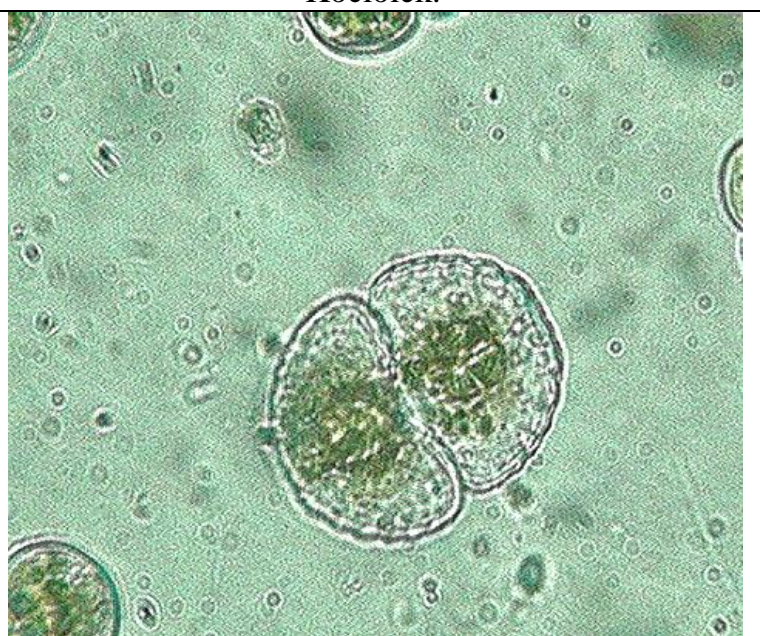

Fig. 15. Cosmarium reniforme (Ralf) Arch. 


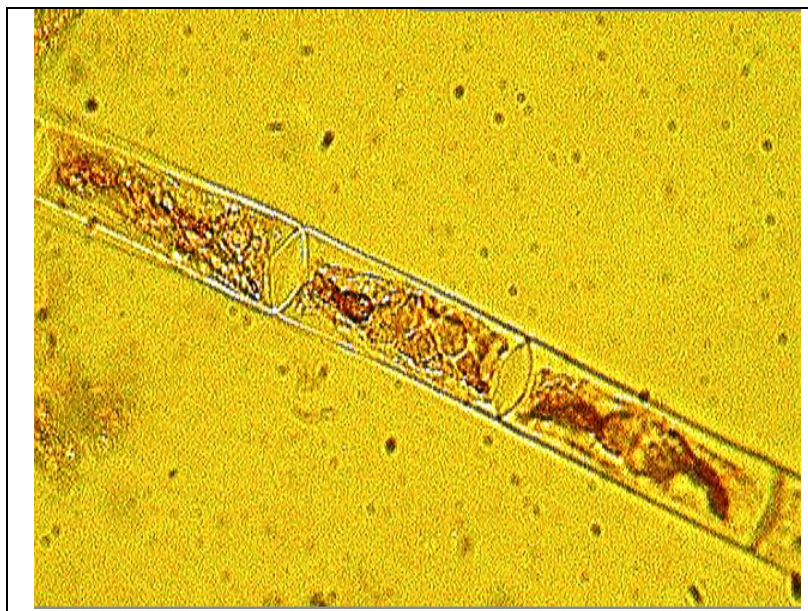

Fig. 16. Mougeotia scalaris Hassall

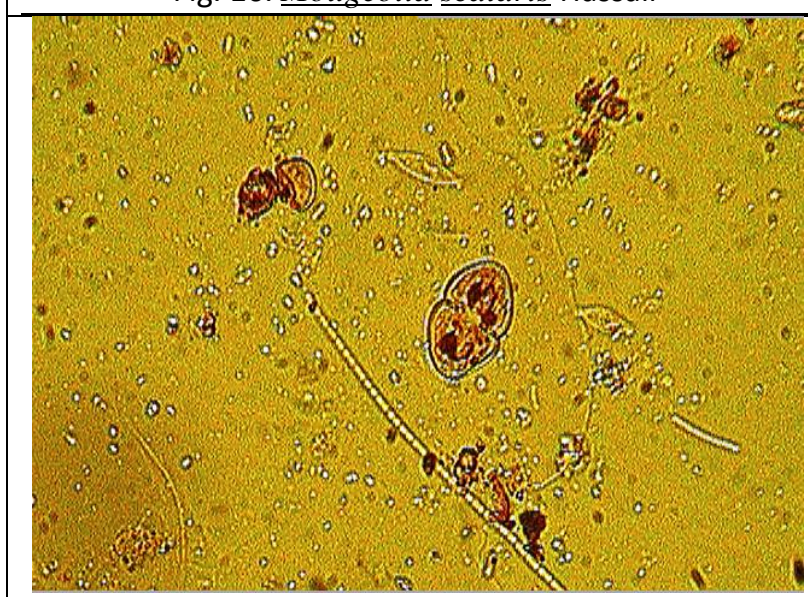

Fig. 18.Cosmarium microsphinctum var. crispulum Nordstedt

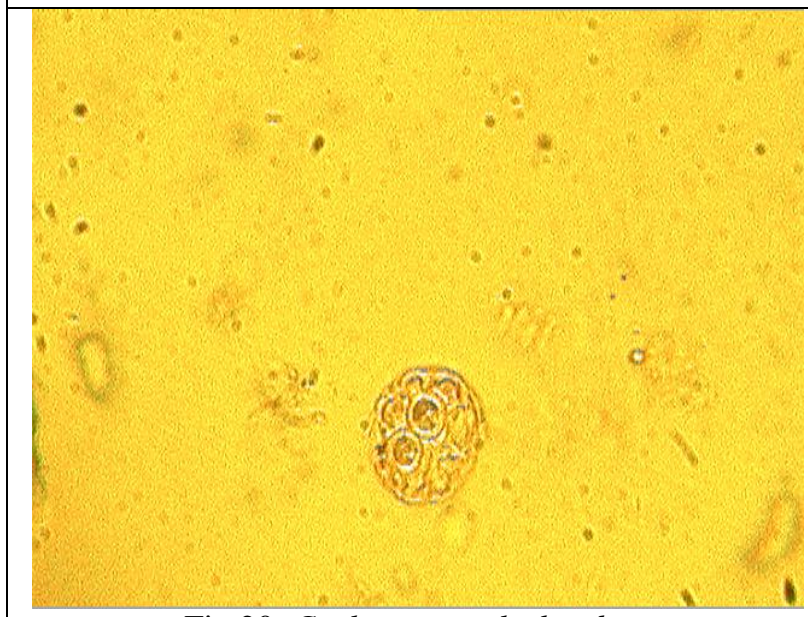

Fig.20. Coelastrum polychordum (Korschikoff) Hindak var. polychordum

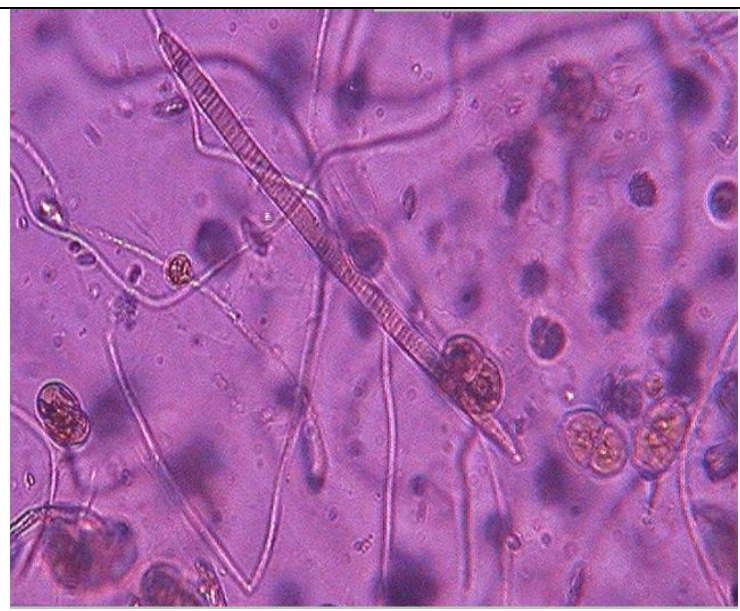

Fig.17. Oscillatoria princeps var. minor Vaucher

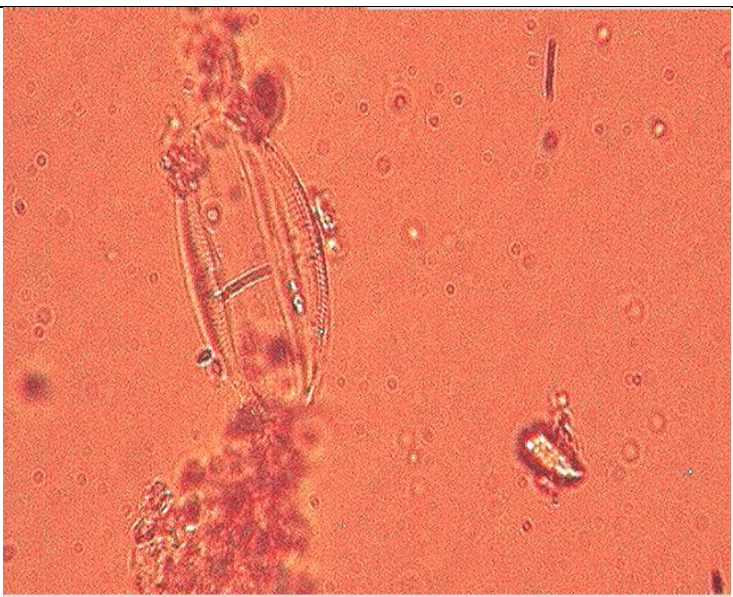

Fig. 19.Amphora copulate (Kutzing) Schoeman \& Archibald

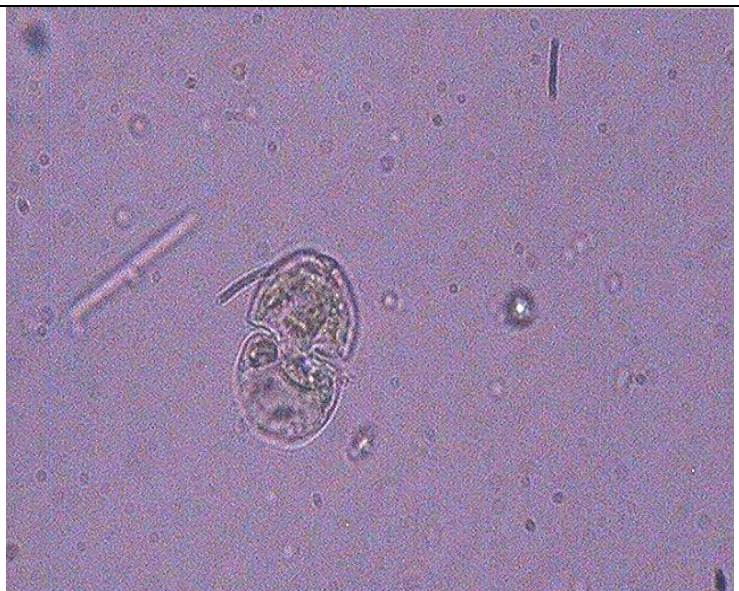

Fig. 21.Cosmarium depressum (Nageli) P.Lundell 


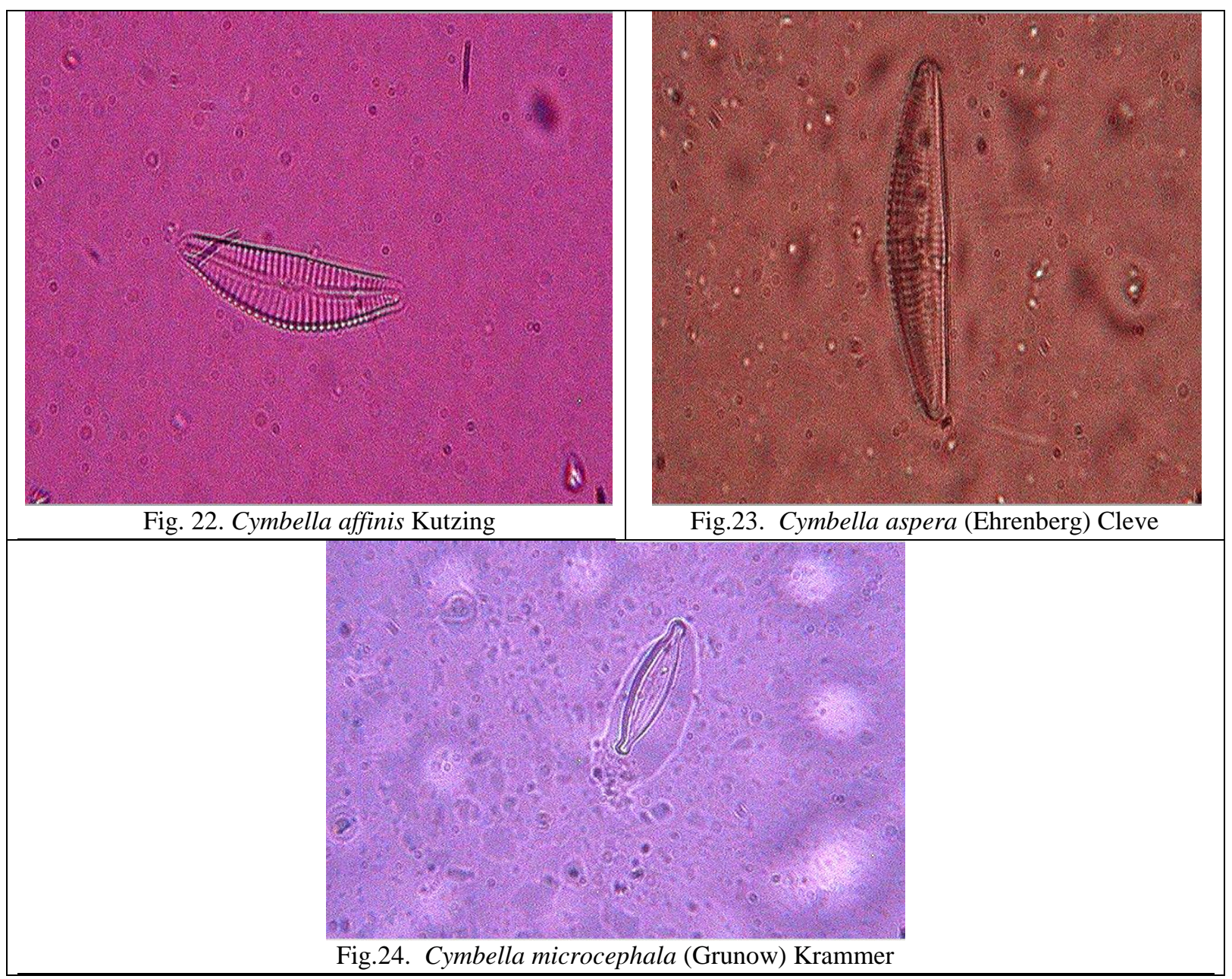

\section{Discussion and conclusion}

In the present work, 21 algal species found in the Vena river of Hinganghat area of Hinganghat tahsil of Wardha District (M.S.) are identified. All these species belong to class Chlorophyceae, Cyanophyceae and Bacillariophyceae. The class wise analysis revealed that Bacillariophyceae is dominant class with nine species followed by Chlorophyceae class with seven species and Cyanophyceae with five species. These observations are well supported by the previous studies of Tarar etal.,(1998) and Desikachary (1959).The information of fresh water algal species was collected based on available literature. The present study gives more emphasis to investigate the unexplored algal flora of the area.

\section{Acknowledgement}

The authors are thankful to the Prof. Dr. S. N. Malode Head, Department of Botany, Govt. Vidarbha Institue of Science and Humanities, Amaravati (M.S.), Dr. Om Mahodaya, Principal, Jankidevi Bajaj College of Science, Wardha and Dr. Bhaskar Ambatkar, Principal, R. S. Bidkar College, Hinganghat Dist. Wardha (M.S.) for their consistent guidance and possible help.

\section{References:-}

[1]. Bharati, S.G., and G.R. Hegde(1982). Desmids from Karnataka State and Goa, Part III. Genus Cosmarium Corda. Nova Hedwigia.36: 733-757.

[2]. Desikachary, T.V. (1959). Cyanophyta, I.C.A.R. monograph on algae, New Delhi. 686p.

[3]. Foged, N. (1971). Fresh water diatom in Thailand. Nova Hedwigia 22: 267-369.

[4]. Patrick, R., and C.W. Reimer (1966). The diatoms of the United States, exclusive of Alaska and Hawaii. Monograph of the Academy of Natural Sciences, Philadelphia, No. 13, Vol. I. 688p.

[5]. Prescott, G.W. (1951). Algae of the western great lakes area. W.M.C. Brown Pub., Dubuque, Iowa. 977p.

[6]. Rai, S.K. (2005). Preliminary report of diatoms from Maipokharilake, Ilam, Nepal. Our Nature.3: 26-30.

[7]. Scott, A.M., and G.W. Prescott (1961). Indonesian desmids. Hydrobiologia 17(1-2): 1-132.

[8]. Sarode P. T., and Kamat. N. D. (1979) Diatom of Marathawada, Maharashtra.

[9]. Sarode, P. T., and Kamat, N. D. (1983) Diatoms flora of Marathawada, Maharashtra

[10]. Tarar, J. L., and Seema Bodkhe(1998). Diatom flora of polluted water bodies of Nagpur. 